Національний фармацевтичний університет, м. Харків

\title{
ПЕДАГОГІЧНІ УМОВИ ВИКОРИСТАННЯ АКТИВНИХ МЕТОДІВ НАВЧАННЯ У ПРОЦЕСІ ПІДГОТОВКИ ФАХІВЦІВ МЕДИЧНОГО ПРОФІЛЮ
}

\author{
I. S. Sabatovska, M. A. Seleznev \\ National University of Pharmacy, Kharkiv \\ PEDAGOGICAL CONDITIONS OF USE ACTIVE \\ LEARNING METHODS IN THE TRAINING OF PROFESSIONAL \\ MEDICAL PROFILE
}

\begin{abstract}
Мета роботи - проаналізувати сутність активних методів навчання, особливості їх використання в освітньому процесі та визначити педагогічні умови, що сприяють підвищенню якості підготовки фахівців медичного профілю.

Основна частина. У статті наводиться аналіз активних методів навчання, визначаються особливості їх використання з метою підвищення якості освітнього процесу та підготовки майбутніх фахівців. Обгрунтовуються педагогічні умови використання активних методів навчання, зокрема у підготовці фахівців медичного профілю. Визначається, що серед основних педагогічних умов $\epsilon$, по-перше, особистість викладача та рівень його педагогічної майстерності, а по-друге - урізноманітнення форм та методів навчання і безпосереднє упровадження активних методів в освітній процес.

Висновок. Підкреслюється, що найбільш ефективний вплив на професійний розвиток лікаря-інтерна, як компетентної особистості та конкурентоспроможного фахівця, здійснюється завдяки застосуванню в освітньому просторі ВНЗ таких активних методів, як: навчання в дискусії, дидактичні ігри, метод ситуаційного аналізу (кейс-метод), мультимедійні засоби навчання, метод моделювання ситуацій (симуляційне навчання) та ін.
\end{abstract}

Ключові слова: педагогічні умови; активні методи навчання; освітні технології; підготовка фахівця.

The aim of the work - to analyze the essence of active methods of teaching, the peculiarities of their use in the educational process and to determine the pedagogical conditions that contribute to the improvement of the quality of medical specialists training.

The main body. The article presents an analysis of the active learning methods and defines the special features of their use to improve quality of the educational process and training of future specialists. Besides of that, we substantiate pedagogical conditions of employment of the active learning methods, particularly in the training of specialists of medical profile. The authors consider that the introduction of such methods is one of the most promising way to improve the training of future professionals, including doctors, and gives necessary knowledge and practical skills to them. The article determines the main pedagogical conditions of the active learning methods in the training of interns such as the identity and pedagogical skills of a teacher and the diversification of forms and methods of training.

Conclusion. We are sure that the method of discussion, the didactic games, the method of situational analysis (case method), the multimedia learning and the method of simulation are the most effective for a professional development of interns.

Key words: pedagogical conditions; active teaching methods; educational technology; training.

Вступ. Одним із актуальних завдань у методиці викладання є перехід на інноваційний шлях розвитку. Активні методи навчання досить швидко були визнані викладачами як дієвий засіб впровадження нових освітніх технологій. Однак використання їх у практиці ВНЗ поки що має фрагментарний, епізодичний, не системний характер внаслідок нерозробленості цих технологій і неготовності більшості

(c) I. С. Сабатовська, М. А. Селезньов викладачів користуватися комп’ютерною технікою та інформаційно-комунікаційними технологіями.

Мета роботи - проаналізувати сутність активних методів навчання, особливості їх використання в освітньому процесі та визначити педагогічні умови, що сприяють підвищенню якості підготовки фахівців медичного профілю. Для вирішення поставленої мети наукових методів дослідження були використані: аналіз психолого-педагогічної літератури, 
діагностичні методи (анкетування, тести, інтерв’ю, бесіди), метод спостереження.

Основна частина. Сучасна орієнтація вищої медичної освіти на формування спроможності до діагностично-лікувальної діяльності та спілкування $з$ пацієнтом вимагає створення педагогічних умов, у яких студент міг би проявити не тільки інтелектуальну та пізнавальну активність, але й особисту соціальну позицію, свою індивідуальність, виразити себе як суб’ єкт навчання. Поняття “педагогічні умови” охоплює компоненти, пов'язані з організацією освітнього процесу, складовими якого є цілі навчання, методи, форми і засоби, а також взаємозалежна навчальна діяльність викладача та майбутніх лікарів. Перед викладачами вищих медичних закладів стоїть важливе завдання - підвищення інтересу студентів й особливо лікарів-інтернів до спеціальних навчальних дисциплін. У сучасної молоді високо розвинені відчуття самосвідомості та власної гідності. Завдяки технічним засобам більш досяжним став великий об’ єм інформації як фахової, так і загальної, розважальної спрямованості.

Інтерни, як і студенти, - різні не тільки за індивідуальними нахилами, але й за знаннями та здібностями. Особлива увага на заняттях має приділятись тим, хто вміє узагальнювати, виділяти головне, відшукувати нешаблонні рішення. Такі інтерни нудьгують при простоях в роботі і постійно мають бути завантажені. Завдання викладача - підтримати в них інтерес до предмета. Водночас у групі $є$ й інтерни з середньою та доброю успішністю. У ході заняття необхідно вчасно помічати їх хоч найменше зростання та навчити бачити закономірності; мислити швидко й абстрактно. $€$ і третя група інтернів - $з$ низьким рівнем підготовки, не впевнених у своїх знаннях, не вміють їх застосовувати. Основне завдання викладача відносно цієї групи - зміцнити в них впевненість у своїх силах, розвинути ініціативу. Вказані факти спонукають шукати і знаходити нові методи та засоби навчання, які сприяють розвитку інтересу до предмета; втілюють у собі взаємну вимогливість та повагу викладача й інтерна; базуються на самосвідомості та вмотивованості майбутніх лікарів. Такі методи збагачують арсенал викладання у вищій медичній освіті.

Активні пізнавальні здібності формуються та розвиваються в процесі пізнавальної діяльності, коли інтерн $\epsilon$ не просто слухачем, а й повноправним учасником навчання - своєю працею видобуває знання. Такі знання є найбільш цінними. Під час активного навчання інтерни більшою мірою стають суб’ єктами навчальної діяльності, вступають у діалог із викладачем, активно задіяні в пізнавальному процесі, виконують творчі, пошукові та проблемні завдання. Під час організації навчання викладач має вирішити такі завдання: навчити інтернів не тільки розуміння завдань, що запропоновані, але і сформулювати їх самому; навчити вміння обрати мету та узагальнити висновки. При цьому необхідним є забезпечити виникнення, збереження та примноження мотивів навчально-пізнавальної діяльності. Характер і результат пізнавальної діяльності залежать від того, який мотив стане вирішальним. Враховуючи вказане, викладач під час своєї діяльності має прагнути до чіткого розуміння та розширення методів мотивації і стимулювання навчальної діяльності інтернів. В основу викладання фахових навчальних дисциплін і практичної підготовки бажано вміщати такі принципи: навчання самостійності; вміння планувати свою діяльність; розвинення волі і цілеспрямованості. Їх досягненню сприяють система диференційованих завдань, накопичувальна система оцінок; діалог та співпраця викладача з інтернами. Активізація пізнавального інтересу сприяє формуванню у них свідомого прагнення до опанування знань та навичок охорони здоров'я.

Так, серед активних методів навчання відзначають технологію аналізу ситуацій, це один 3 найбільш ефективних і поширених методів організації активної пізнавальної діяльності лікарів-інтернів. Цей метод розвиває здібність до аналізу життєвих і професійних завдань. Технології аналізу ситуацій дозволяють розвивати аналітичні здібності і критичне мислення; більш обмірковано поєднувати теоретичні знання з практикою, формувати навички оцінки альтернативних варіантів в умовах невизначеності, точно виражати свою точку зору й аргументувати іï, формувати навичку вирішення комплексних завдань, що має важливе значення для практичної діяльності майбутнього фахівця. Найчастіше використовуються: метод ситуаційного аналізу, що містить аналіз конкретних ситуацій (ситуаційні завдання, ситуаційні вправи), метод ситуаційного навчання - метод кейсів.

Важливою особливістю кейс-методу є можливість його інтеграції з різними іншими методами активного навчання (дискусія, “мозковий штурм”, ігрові методи, метод опису, моделювання тощо). Під кейсом розуміють складний, проблемний, цікавий клінічний випадок, з яким лікарі-інтерни можуть зустрітися під час їх практичної ді- 
яльності (пакет, що містить скарги, анамнез, дані об’єктивного статусу з наданням ілюстративних матеріалів, дані лабораторних та інструментальних досліджень, діагноз (попередній, можливо помилковий), лікування (можливо помилкове, або таке, що не відповідає протоколам), динаміку стану хворого (ефективність проведеного лікування, побічні дії на застосовані ліки тощо). Кейси можуть бути індивідуальними або розрахованими на групу осіб, містити додаткові тестові завдання, посилання на літературні джерела тощо. Кейс-метод сприяє розвитку клінічного мислення, удосконаленню навичок вирішення проблеми, впливає на професіоналізацію та виховання колегіальності, тому його застосування як методу активного навчання $є$ перспективним напрямом інтенсифікації навчання [1].

Такий метод активного навчання, як “спрямована дискусія”, орієнтований на те, що ключем до обговорення є вміння задавати дискусійні питання. Завдання викладача - допомогти групі виділити певну проблему, спрямувати хід обговорення в сторону прояснення і вирішення цієї проблеми. Використовуючи відповіді і міркування, висловлені інтернами, з тим, щоб зробити акцент на правильному положенні, викладач залучає до роботи над матеріалом і підвищує їх зацікавленість в обговорюваному питанні. У процесі навчання лікар-інтерн має бути підготовлений до зустрічі з будь-яким пацієнтом і будь-якою патологією. Тому “розкріпачення” лікарів-інтернів і навчання їх необхідних практичних навичок та логічного мислення - найважливіше завдання викладання.

На наш погляд, досить ефективним методом набуття практичних знань і навичок є “ділова гра”. Це один із методів активного навчання, який визначає три найважливіші напрями, що поліпшують якість навчання порівняно з традиційними методами та іншими методами й засобами навчання, це: оптимізація професійного мислення за допомогою навчальних алгоритмів; оптимізація професійних умінь і навичок за допомогою програмованого навчання; моделювання професійної діяльності, найвища форма якого - дидактична гра як новий ефективний метод підготовки лікаря. Сенс навчальної ігрової імітації полягає в тому, щоб виховати в лікаря-інтерна практичне уміння безпомилкової диференційної діагностики, клінічно схожих захворювань, економного встановлення достовірного діагнозу й оптимального лікування хворого в найкоротші терміни. У процесі підготовки до ділової гри у лікарів-інтернів з’являється мотив для активного пошуку діагностичної інформації відповідно до виконуваної ним ролі, виробляється навичка роботи з отриманою інформацією. Лікарінтерн виробляє навичку контролю своєї поведінки, вчиться адекватно сприймати та аналізувати чужу думку. Переваги ділової гри серед інших видів навчання полягають у тому, що вона, імітуючи ситуації, реальні у майбутній професії, розвиває уміння шукати і працювати з інформацією, дозволяє значно активізувати творчі можливості лікаря-інтерна, дає можливість вчитися на своїх і чужих помилках.

Важливим компонентом підготовки майбутніх лікарів до їх подальшої трудової діяльності є використання комп’ютерної техніки в освітньому процесі [2]. Виокремлюють три основні форми, в яких комп’ютер слід застосовувати при використанні його навчаючих функцій: як тренажер, як репетитор та як пристрій, що може моделювати різні клінічні ситуації. Комп’ютерна техніка дає можливість відпрацювання і закріплення знань та умінь із використанням дидактичного матеріалу в різних формах: у вигляді тестових завдань, додаткового матеріалу (схеми, рисунки, таблиці). Серед активних методів навчання значне місце продовжують займати мультимедійні системи, які надають користувачеві комп’ютера такі види інформації, як: текст, зображення, анімаційні картинки, аудіокоментарі, цифрове відео. Мультимедійне навчання - це навчання із комплексом апаратних і програмних засобів, що дозволяють спілкуватися з комп’ютером, використовуючи різноманітні середовища: графіку, гіпертексти, звук, анімацію, відео. Це технології, які дозволяють за допомогою комп’ютера інтегрувати, обробляти і водночас відтворювати різноманітні типи сигналів, різні середовища, засоби і способи обміну інформацією. Правильне, доцільне використання таких інформаційно-комп’ютерних технологій у навчальному процесі сприяє активізації пізнавальної діяльності інтерна, наприклад, за рахунок комп’ютерної візуалізації певної інформації під час читання лекцій і проведення практичних занять.

Переваги використання комп'ютерних технологій у навчальній роботі з лікарями-інтернами можна звести до двох груп: 1) технічні переваги (швидкість, маневреність, оперативність, можливість перегляду і прослуховування фрагментів та інші мультимедійні функції); 2) дидактичні переваги (створення ефекту присутності, відчуття автентичності, реальності подій, інтерес, бажання дізнатися і побачити більше). 
Головними перевагами так званої електронної форми подання навчально-виховної інформації $€$ компактність, значні можливості щодо вираження сутності та особливостей подання навчального матеріалу (відео, звук, анімації), інтерактивність тощо. Поряд із цим, необхідно відзначити, що в медичній освіті вони ні в якому разі не можуть повністю замінити традиційну форму навчання, що передбачає участь викладача, інтерна і хворого. I тому слід уникати непродуманого, надмірного застосування комп’ютерних технологій, що може не покращити, а погіршити якість засвоєння знань та умінь лікарямиінтернами, якщо це буде представлено у вигляді механічного перенесення інформації з підручників і посібників на електронні носії.

Поширення також набуває симуляційне навчання, прикладами чого стають відкриття при медичних навчальних закладах певних симуляційних центрів. Завдяки симулятивному навчанню, як одного із методів, що активізує пізнавальну діяльність, лікарі-інтерни мають змогу отримувати не тільки теоретичні знання, а й удосконалювати практичні навички, відпрацьовувати моделі поведінки медичного персоналу при виникненні критичних ситуацій у медичній практиці. Клінічні ситуації, які вимагають надання невідкладної допомоги, за допомогою манекена можна відтворювати з будь-якою необхідною кількістю повторів в умовах, повністю відповідних до реальності. Тобто відбувається підготовка лікарів-інтернів до “зустрічі” з реальним пацієнтом. Курс так званої “фантомної” підготовки дозволяє відпрацювати до автоматизму навички накладення хірургічних щипців тощо. Викладач може змоделювати будь-який сценарій, включаючи фонове соматичне захворювання людини. Це дозволяє не тільки виконувати стандартні навички надання допомоги, але на їх основі тренувати клінічне мислення з динамічною оцінкою клінічної ситуації, у тому числі при відповіді на різні маніпуляції і лікарські препарати.

На нашу думку, активна пізнавальна діяльність забезпечує розкриття нових можливостей інтернів та є необхідною умовою для формування ключових компетенцій майбутнього лікаря. Використання активних технологій і методів навчання у підготовці фахівців медичних ВНЗ дозволяє успішно розвивати професійність, стимулювати й активізувати пізнавальну активність лікарів-інтернів, добиватися високого ступеня самостійності.

Таким чином, проаналізувавши особливості активних методів навчання у процесі підготовки лікарів-інтернів, вважаємо, що основними педагогічними умовами їх реалізації є: 1) особистість викладача та рівень його педагогічної майстерності; 2) урізноманітнення форм та методів навчання; упровадження активних методів. Детальніше їх представлено на рисунку 1.

Поряд із цим, слід приділити увагу організації предметного середовища, що створює комфортні умови навчальної діяльності (створення особистісно орієнтованого середовища, надання можливості інтернам брати участь у семінарах, конференціях, майстер-класах, мета яких - отримання нової професійно важливої інформації, створення ситуації успіху).

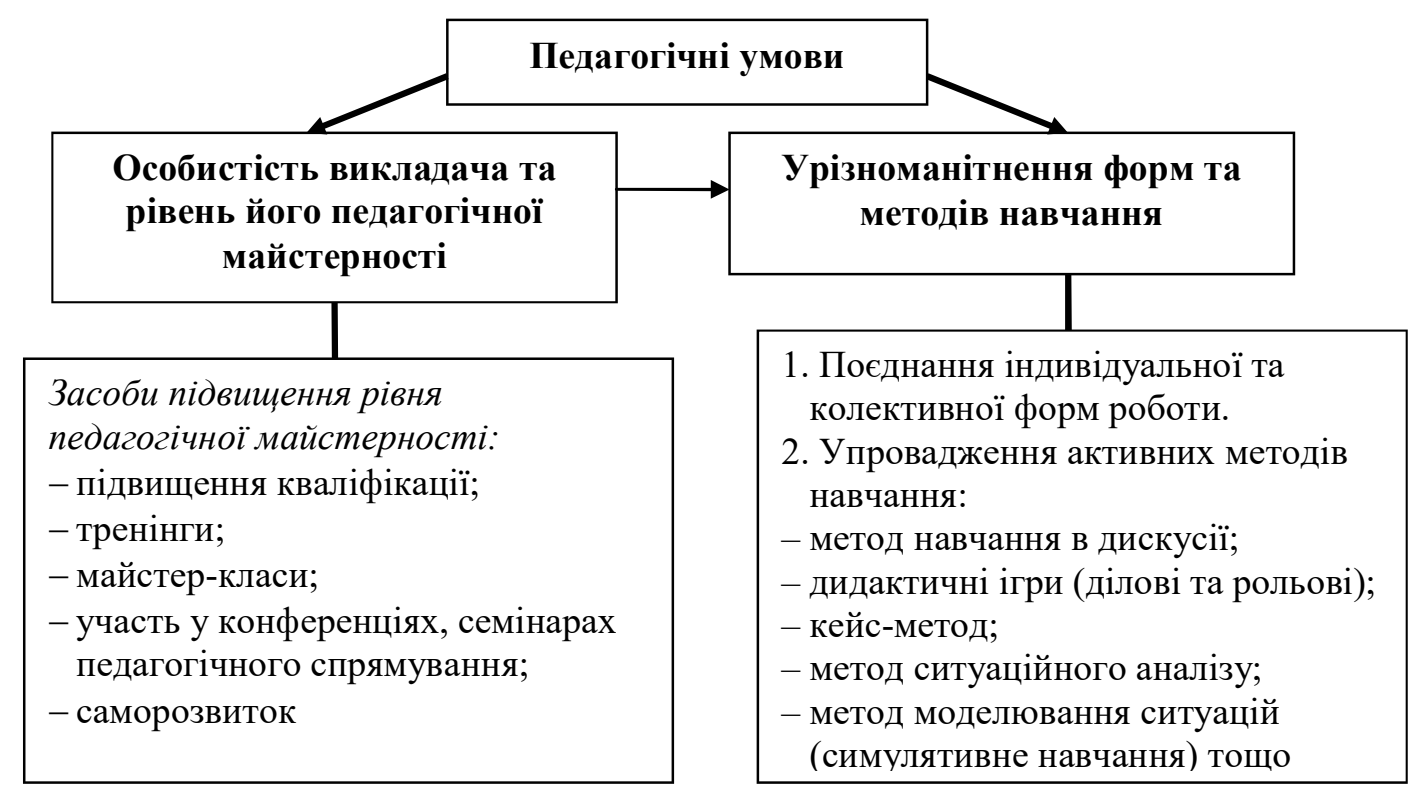

Рис. 1. Педагогічні умови використання активних методів навчання. 
Висновок. Впровадження активних форм та методів навчання є одним із найперспективніших шляхів удосконалення підготовки майбутніх фахівців, зокрема лікарів, озброєння їх потрібними знаннями і практичними навичками. На наш погляд, до основних педагогічних умов використання активних методів навчання у процесі підготовки лікарів-інтернів можна віднести: 1) особистість викладача та рівень його педагогічної майстерності; 2) урізноманітнення форм та методів навчання;

\section{Список літератури}

1. Пометун О. І. Інтерактивні технології навчання: теорія, досвід : метод. посіб. / О. І. Пометун, Л. В. Пироженко. - К. : А.П.Н., 2002. - 136 с.

2. Вороненко Ю. В. Розвиток нових технологій у післядипломній освіті лікарів і провізорів: тенденції, експертні висновки та реальні оцінки ефективності навчання / Ю. В. Вороненко, О. П. Мінцер // Мед. освіта. - 2013. № 2. - C. 19-23.

\section{References}

1. Pometun, O.I., \& Pyrozhenko, L. (2002). Interaktyvni tekhnolohii navchannia: Teoriia, dosvid: metod. posib. [Interactive technologies of education: Theory, experience: methodical manual]. Kyiv: A.P.N. [in Ukrainian].

2. Voronenko, Yu.V., \& Mintser, Yu.V. (2013). Rozvytok novykh tekhnolohii u pisliadyplomnii osviti likariv i provizoriv: tendentsii, ekspertni vysnovky ta realni otsinky efektyvnosti navchannia [Development of new technologies in postgraduate education of doctors and pharmacists: trends, expert conclusions and real assessments of educational упровадження активних методів. Вважаємо, що найбільш ефективний вплив на професійний розвиток лікаря-інтерна, як компетентної особистості та конкурентоспроможного фахівця, здійснюється завдяки застосуванню в освітньому просторі ВНЗ таких активних методів, як: метод навчання в дискусії, дидактичні ігри, метод ситуаційного аналізу (кейс-метод), мультимедійні засоби навчання, метод моделювання ситуацій (симуляційне навчання) та ін.

3. Кайдалова Л. Г. Сучасні педагогічні технології : навч. посіб. для магістрантів, викладачів, аспірантів / Л. Г. Кайдалова, Н. Б. Щокіна. - Х. : Вид-во НФаУ, 2012. - 107 с.

4. http://www.pontydysgu.org/2010/01/crowd-sourcingthe-european-foresight-study-your=chance-to-be-an-expert/ Освіта в Європі у 2020-2030 роках. Прогноз.

effectiveness]. Med. Osvita - Medical Education, (2), 19-23 [in Ukrainian].

3. Kaidalova, L.H., \& Shchokina, N.B. (2012). Suchasni pedahohichni tekhnolohii: Navch. posib. dlia mahistrantiv, vykladachiv, aspirantiv [Modern pedagogical technologies: teaching. manual for graduate students, faculty, postgraduates]. Kharkiv: Vyd-vo NfaU [in Ukrainian].

4. Osvita v Yevropi u 2020-2030 rokakh. Prohnoz [Education in Europe in 2020-2030. Forecast]. Retrieved from: http://www.pontydysgu.org/2010/01/crowd-sourcingthe-european-foresight-study-your=chance-to-be-an-expert/-. 